Article

\title{
Corporate Derivatives and Ownership Concentration: Empirical Evidence of Non-Financial Firms Listed on Pakistan Stock Exchange
}

\author{
Affaf Asghar Butt ${ }^{1}$, Main Sajid Nazir ${ }^{2}$, Hamera Arshad ${ }^{3}$ and Aamer Shahzad ${ }^{3, *(D)}$ \\ 1 Department of Business Administration, University of The Punjab, Gujranwala Campus, \\ Punjab 52250, Pakistan; affaf.butt@pugc.edu.pk \\ 2 Department of Management Sciences, COMSATS University, Islamabad, Lahore Campus, \\ Punjab 54000, Pakistan; snazir@ciitlahore.edu.pk \\ 3 Department of Business Administration and Commerce, University of Sargodha, Gujranwala Campus, \\ Punjab 52250, Pakistan; humairaarshad394@gmail.com \\ * Correspondence: aamer.shahzad@uosgc.edu.pk
}

Received: 10 May 2018; Accepted: 15 June 2018; Published: 27 June 2018

\begin{abstract}
Risk management has been gaining tremendous fame for the last couple of years. Firms in developed and developing countries are facing a variety of risks, i.e., foreign exchange risk, interest rate risk, commodity price risk, and equity risk. It calls for such hedging techniques that mitigate this risk level, thus, allowing corporations to enjoy a solid return. This paper draws attention to a new determinant of hedging, i.e., the role of ownership concentration in risk management using derivative instruments. For this purpose, a sample data of 101 non-financial firms listed on the Pakistan Stock Exchange (PSX) for six years, ranging from 2010-2016, is used. The Mann-Whitney test for difference in users and no-users is applied along with logistic regression to check the effect of ownership concentration on derivative usage. The finding of this study reveals that concentrated owners are less likely to use derivatives for hedging purposes due to concentrated owners' interests (top five shareholders \& largest shareholder, family owners). Whereas, executives are more likely to engage in the use of derivatives to increase the value of their stocks. However, associated companies are significantly less involved in hedging activities. These results are extremely advantageous for policymakers in corporations to create a more stable corporate environment.
\end{abstract}

Keywords: ownership concentration; derivatives usage; hedging

\section{Introduction}

One of the unresolved questions linked with firms' financial decisions is why firms hedge with derivatives. Various explanations, in this sense, have been postulated and empirically tested, but the findings are inconclusive. In the contemporary business world, the use of derivatives (a proxy for risk management) to manage risk has amplified during the last decade. According to Levi (1996), a corporate risk management system can be viewed in different ways, such as derivatives, foreign currency debt, and effective hedging. Specifically, non-financial firms intensively use financial derivatives to manage their financial risks, such as interest rate risk and financial risk (Berkman et al. 1997; Bodnar et al. 1998; Hagelin 2003). Due to intense competition, corporations have been encouraged to expand their businesses by passing national boundaries to benefit from economies of scale and a competitive advantage. Moreover, firms are also engaged in international business to achieve the benefits of low prices or to penetrate foreign markets, which can lead to foreign exchange exposure (Afza and Alam 2011b). Likewise, most investors have become embroiled in the trade of commodities and invested in poorly diversified portfolios, which may increase commodity price risk 
and equity risk to a considerable extent (Hagelin et al. 2006). Fluctuations in interest rates may also influence the cost of borrowing and also affect firms' profitability (Mahmood and Rehman 2010). Thus, the use of derivative instruments for hedging is a cost-effective way to reduce overall risk exposure (Grant and Marshall 1997).

Since the Asian financial crises in 1998 and the U.S financial crunch in 2007, there has been a dramatic change in risk management strategies. The demand curve of derivative instruments has shifted upwards to curtail cash flow sensitivity (Afza and Alam 2011b). Corporate risk management theories by (Smith and Stulz 1985; Bessembinder 1991) and agency cost and risk management theory by (Leland 1998) have postulated that the use of derivatives for managing risk is necessary to enhance firms' value by curbing financial distress cost, underinvestment cost, agency cost, and expected tax liability. Ample empirical evidence focuses on the use of derivative instruments and their impact on risk. This strand investigates whether the use of derivatives is consistent with existing hedging theories (Tufano 1996; Géczy et al. 2007; Haushalter 2000; Graham and Rogers 2002), whether the motivation behind their use is speculation (Géczy et al. 2007), or whether the use of derivatives impacts risk (Guay 1999; Allayannis and Ofek 2001; Zhang 2009; Bartram et al. 2011). In this connection, ample evidence has been provided that discusses the significance of derivatives. However, the question, "When and which type of derivative is used for beating risk?" remains unanswered (Bodnar et al. 1998; Hagelin 2003).

Good corporate governance is necessary to work in the derivative market. Conflict arises between managers and shareholders when these two parties understand the motivation behind the use of derivatives separately. Corporate governance is a set of contractual and legal precautions that shareholders employ to minimize these conflicts. Despite the importance of derivatives, good corporate governance is a yardstick of success that is also translated into firm value. Compliance with governance mechanisms restricts management to channel their energies away from value-destroying activities and into value-creating activities, and, ultimately, in this way, shareholders' rights are protected. It also develops a system for effectively implementing derivative instruments for hedging purposes. One of the robust mechanisms of corporate governance is the ownership structure of a company. Ownership structure particularly shapes firms' decisions regarding hedging activities (Osuoha 2013). Firms' internal block holders have different incentives than external block holders. The misalignment of interest between internal and external block holders can lead firms towards financial risks (Allayannis et al. 2011). Thus, the use of derivatives provides an expedient way to curtail corporates' risks and must be considered by managers. The implications of derivatives for hedging motivate the executive's owners to increase the value of their stock (Lel 2012). There is another concern regarding derivatives' usage; family owners are different from non-family owners as they have undiversified and sizeable holdings within a corporation. Therefore, hedging activities offer a convenient way to reduce personal risks faced by them (Tungsong and Jiraporn 2017).

Prior academic research on derivatives has been conducted on the relationship between corporate governance and the use of derivative instruments, especially in developed countries (Allayannis et al. 2011; Lel 2012; Osuoha et al. 2015; Tashfeen et al. 2017). Limited evidence is found in Pakistan regarding determinants of derivatives and their impact on the value of the firm (Afza and Alam 2011b; Chaudhry et al. 2014b; Tashfeen et al. 2017).

However, in emerging economies, very little is known about how ownership concentration deals with derivatives using policies. To the best of our knowledge, no study has been found in the context of Pakistan. The purpose of the present study is to fill this gap by discussing the unique case of Pakistan using a sample of 101 non-financial firms listed on the Pakistan Stock Exchange (PSX) for the period, ranging from 2010 to 2016. The present study employed various proxies to capture the ownership structure, such as shareholder ownership (the ratio of top five shareholdings, the ratio of most substantial shareholding), the ratio of family ownership and managerial ownership (the ratio of executive ownership, the ratio of the largest director), and, lastly, the ratio of associated companies. 
The rest of the study is organized as follows. A literature review is discussed in Section 2. Section 3 outlines the samples, data collection, and analysis techniques. Empirical findings are presented in Section 4 . Section 4 provides final remarks.

\section{Literature Review}

\subsection{Derivatives and Risk Mitigation}

Derivatives and risk management move side by side. The use of derivatives leads toward lower risk, which results in less volatility in corporate cash flows. Allayannis and Weston (2001) were pioneers in discussing the valuation aspects of derivatives' usage on foreign exchange exposure in a sample data of 720 non-financial firms during the period, 1990-1995. They revealed that the use of foreign exchange derivatives significantly reduced foreign exchange exposure and, thus, increases firms' value. Grant and Marshall (1997) investigated the influence of financial derivatives (i.e., forward, interest rate swaps, \& options) on risk mitigation by surveying treasures of large UK companies. This positive influence postulated that the widespread use of financial derivatives was attributed to the effective management of interest rate risk and currency risk. Afterward, Hagelin (2003) anatomized the impact of currency derivatives on transaction exposure hedges through a sample of 160 Swedish firms in 1997. The results showed a significant positive relation between currency derivatives and transaction exposure hedges. It also depicted that the usage of currency derivatives may increase a firm's value by minimizing financial distress costs and underinvestment issues.

Contrary to this, Anton (2013) analyzed risk management practices adopted by the 26 Romanian metallurgical enterprises listed on the Bucharest Stock Exchange in 2011. The findings delineated that companies positively used financial derivatives (i.e., forwards, interest rate swaps, and options) to manage commodity price risk and currency risk. Horng and Wei (1999) explored the association of interest rate derivatives (swaps) with the hedging of 186 real estate investment trusts (REIT) industry. This analysis portrayed the positive relationship between interest rate derivatives and hedging. Titman (1992) further posited that information asymmetry and expected performance improvement might also lead to increased use of interest rate swaps to take advantage of borrowing swapping into a fixed rate payment. Geczy et al. (1997) scrutinized the effect of currency derivatives (i.e., currency swaps, forwards, futures, and options) on the risk management of 372 large U.S. firms in 1990. The results showed that firms with high growth opportunities and lower access to internal and external financing had a positive impact on currency derivatives to reduce currency risk.

\subsection{Derivatives, Corporate Governance, and Risk Mitigation}

Risk mitigation using derivatives is an essential factor in corporate governance. In this regard, Tashfeen and Azhar (2016) argued that corporate governance within a firm encourage managers to use derivative hedging practices along with investment, financial, and operational strategies for the best interest of the company and its shareholders. Further, Tashfeen et al. (2017) also scrutinized the impact of corporate governance on the uses of financial derivatives of non-financial firms listed on the New York Stock Exchange during the period, 2004-2011. The results indicated that board independence, board diversity, board meetings, block holders, Chief Executive Officer (CEO) age, and CEO tenure did not show any significant effect on firms' hedging decisions. Whereas, institutional shareholders, CEO base salary, and $\mathrm{CEO}$ bonus were significantly and positively related to the use of financial derivatives by the firm. Also, Al-Shboul and Alison (2009) postulated that corporate governance provides a system for efficiently managing derivatives' usage within a company for the benefits of shareholders.

By considering the strength of corporate governance in accordance to derivative usage, Lel (2012) examined the relationship between currency hedging and corporate governance of 543 non-financial firms from thirty countries, spanning the period, 1990-1999. The results portrayed that excellent governance has a positive association with derivatives' hedging decisions to reduce currency risk and external financing costs. Contrastingly, firms with weak governance made positive use of derivatives 
for managers' interests, i.e., repute building or securing pet projects. Similarly, Osuoha et al. (2015) investigated the impact of corporate governance on derivatives' usage of 760 African non-financial firms from seventeen African countries. They found that strongly governed firms positively use derivatives to mitigate risks and that the board composition is the dominant mechanism of corporate governance that had an impact on the uses of derivatives.

Contrary, Dionne and Triki (2013) investigated the use of derivatives about board independence and chairman independence by utilizing sample data of 48 North American gold mining firms, ranging from 1991-1999. The results demonstrated that both chairman independence and board independence mechanisms were positively linked with derivative usage to support hedging activities. Also, Huang et al. (2013) analyzed the impact of audit committee expertise, board independence, and CEO equity holding on derivative usage. The results showed that those firms making significant use of derivatives for hedging purposes had less independent directors on the board and higher CEO shareholding. They also found that the audit committee expertise had no significant impact on firms 'decisions regarding derivative usage.

To the extent that ownership structure also particularly shapes firms' decisions regarding hedging activities, Boubaker et al. (2010) determined the effect of ownership structure on the uses of derivatives in a sample data of 262 French non-financial firms listed on the Paris Stock Exchange, spanning the period, 1999-2000. They found that firms' ownership structure had a significant impact on firms' decisions concerning derivatives' usage. They also postulated that CEO ownership could negatively affect decisions to use derivatives. Hagelin et al. (2007) explored that CEO ownership could have a negative impact on derivative usage to reduce risk if the CEO comes from a family that is the largest shareholder in the firm. Furthermore, Hagelin et al. (2006) evaluated the impact of family-controlled firms on derivatives' usage of 427 Sweden non-financial firms listed on the Stockholm stock exchange, ranging from 1997-2001. The results depicted that the largest shareholder who came from a family and firms that are controlled by family owners were significantly and negatively associated with financial hedging.

Another aspect of ownership structure, such as managerial ownership and institutional ownership, also have a significant relationship with hedging and the uses of derivatives. Adkins et al. (2007) examined the relationship between managerial ownership, institutional ownership, and foreign exchange derivatives of 252 large U.S bank holding companies during the period, 1996-2000. They concluded that high percentages of shares held by institutions were positively and significantly linked with the use of derivatives to minimize foreign exchange risk. This study also found that managerial ownership had a positive influence on derivative usage as large institutional shareholders incentivized them to use derivatives to mitigate foreign exchange rate risk. Similarly, Spanò (2007) portrayed that managers with a higher percentage of stock ownership positively used derivatives to truncate risk in the best interest of shareholders. Al-Shboul and Alison (2009) investigated the effect of institutional ownership and directors' ownership on derivative usage by using the ownership structures of 62 Australian multinational companies as a sample. The results showed that institutional ownership was significantly and positively related to foreign exchange derivatives, whereas, directors' ownership was not significantly linked with the use of such derivatives to diminish foreign exchange exposure. Also, Borokhovich et al. (2004) described that outside directors on the board positively use interest rate derivatives for employing hedging activities rather than internal ones. On the other hand, Wang and Fan (2011) proposed that external block holders who hold five percent or more of the common stock in a company are negatively related with the use of derivatives to alleviate risk as they prefer to decrease risk by diversifying their investment in more than one company. Indeed, Whalley (2008) viewed the impact of executives' ownership on hedging and provided evidence that executives positively make use of derivatives to hedge and enhance the essential value of their stock options, while stock ownership may not encourage them to use derivatives for hedging. 


\subsection{Derivatives and Pakistan}

Since the last decade, different comparative studies have also been conducted on the use of derivatives in Pakistan. Bashir et al. (2013) scrutinized the uses of foreign currency and interest rate derivatives of 107 non-financial firms in Pakistan listed on the Karachi Stock Exchange, ranging from 2006-2010. The results revealed that firms positively use derivatives to curtail financial risks, while the uses of derivatives have no significant effect on firms' value. Chaudhry et al. (2014b) also investigated the use of derivatives in Pakistan in a sample data of 75 non-financial firms listed on the Karachi Stock Exchange from 2007 to 2011. The results demonstrated that the firms that positively and significantly used derivatives to apply appropriate risk management strategies enjoyed economies of scale and high profitability, which, ultimately, enhanced the firms' value.

By analyzing firm's decisions regarding hedging policies, Chaudhry et al. (2014b) further identified that large size firms that have high growth opportunities and higher import volume significantly and positively use derivatives to hedge interest rates and exchange rate exposures. Furthermore, Afza and Alam (2011a) also examined the determinants of financial derivatives' usage by taking 105 non-financial firms listed on the Karachi stock exchange as a sample during the period, 2004-2008. The findings showed that firms use positively and significant foreign exchange derivatives to minimize financial hazards costs, cash flow volatility, tax convexity, and underinvestment issues. Again, Afza and Alam (2011a) revealed that, in Pakistan, only those companies that make positive use of foreign exchange derivatives to reduce risk had high foreign sales volume. Contrastingly, Mahmood and Rehman (2010) analyzed the uses of derivatives in Pakistani firms using a sample data of 67 non-financial firms. The findings of this study indicated that the use of derivative instruments in Pakistan is minimal due to a lack of knowledge about modern finance, low awareness of derivatives, weak economic conditions, and Pakistan's weak derivative market.

Almost all identified researchers have confirmed the positive and significant role of derivatives' usage in risk mitigation, while some variables of corporate governance depicted a negative relationship with derivative usage. However, some of the investigations have used a small sample from a particular sector, and these results may not be generalized to all corporations in Pakistan. Also, most of the studies emphasized another dimension of corporate governance (i.e., board independence, board composition, board size), while omitting the role of ownership structure as a whole in derivative usage. Hence, this generates a significant research gap still available to be analyzed. Given the above contemplation, the current study expects to fill the research gap in the literature and dissect the relationship between ownership concentration and firms' hedging in Pakistan by forming the following hypotheses:

H1. There exists a negative relationship between ownership concentration and the use of derivatives and

H2. The use of derivatives increases when directors have a stake in the firm's ownership.

\section{Data and Methods}

According to the International Accounting Standards (IAS) 32 and 39, firms must disclose their usage of hedging tools in their financial reports. In this regard, the present study collects data from audited annual financial reports of non-financial firms and has covered a period of six years, ranging from 2011 to 2016. The total listed firms on the Pakistan Stock Exchange (PSX) were 554 firms as on 31 December 2016. These firms are divided into 384 non-financial and 170 financial firms. The final sample comprises 101 non-financial firms and 700 firm-year observations. The purpose of this study is to investigate the impact of ownership concentration on the use of derivatives. The sample data have also been subdivided into two groups; derivative users and non-derivative users.

The study used categorical variables (binary variable), one for derivative users and zero for non-users.

$$
D E V=\left(\begin{array}{cc}
1 & \text { derivative users } \\
0 & \text { derivative non }- \text { users }
\end{array}\right)
$$


When a dependent variable is categorical, the ordinary least squares (OLS) method can no longer produce the best linear unbiased estimator (BLUE); that is, OLS is biased and inefficient. Categorical dependent variable models adopt the maximum likelihood (ML) estimation method, whereas OLS uses the moment based method. The ML method requires an assumption about probability distribution functions, such as the logistic function and the complementary log-log function. Logit models use the standard logistic probability distribution.

The binary logit model is represented as

$$
\operatorname{Prob}(y=1 \mid x)=\Lambda(x B)=\Lambda \frac{\exp (x B)}{1+\exp (x b)}
$$

Where $\Lambda$ indicates a link function, the cumulative standard logistic distribution function. This study also used some control variables in its empirical models, such as the size of firms, leverage, financial distress costs, and foreign sales with ownership. By following (Fok et al. 1997), we used logit regression analysis to examine the effect of ownership, and firm-specific variables on the usage of derivatives and, mathematically, logistic regression estimates a multiple linear regression functions defined as:

$$
\begin{aligned}
& \log \left(\frac{\pi}{1-\pi}\right)=\beta_{0}+\beta_{1} \cdot\left(\mathrm{RTOP5}_{\mathrm{i} 1}, \mathrm{RLS}_{\mathrm{i} 1}, \mathrm{RFO}_{\mathrm{i} 1}, \mathrm{RAC}_{\mathrm{i} 1}, \mathrm{REO}_{\mathrm{i} 1}\right) \\
& +\beta_{2} \cdot \mathrm{EPS}_{\mathrm{i} 2}+\beta_{3} \cdot \mathrm{SIZE}_{\mathrm{i} 3}+\beta_{4} \cdot \mathrm{LEV}_{\mathrm{i} 4}+\beta_{5} \cdot \mathrm{FDC}_{\mathrm{i} 5}+\beta_{6} \cdot \mathrm{FSlog}_{\mathrm{i} 6}
\end{aligned}
$$

Table 1 provides the summary of all variables used in this study. The Mann-Whitney $U$ test is used to analyze the difference between derivative users and non-users. Marginal effects and discrete changes are very useful when interpreting the result of a binary logit model. The marginal effect of a continuous independent variable, $x_{\mathrm{c}}$, is the partial derivative concerning that variable. The discrete change of a binary independent variable (dummy variable), $x_{\mathrm{b}}$, is the difference in predicted probabilities of $x_{\mathrm{b}}=1$ and $x_{\mathrm{b}}=0$, holding all other independent variables constant at their reference points. $x_{\mathrm{b}}$ denotes all independent variables other than $x_{\mathrm{b}}$ Marginal effects and discrete changes look similar but are not equal in conceptual and numerical senses.

$$
\begin{gathered}
\frac{\partial \mathrm{P}(y=1 \mid x)}{\partial x_{c}}=\frac{\exp \left(x_{b}\right)}{\left[1+\exp \left(x_{b}\right)\right]^{2}}=\Lambda(x \beta)\left(1-\Lambda(x \beta) \beta_{c}\left(\text { marginal effect of } x_{c}\right)\right. \\
\left.\frac{\Delta \mathrm{P}(y=1 \mid x)}{\Delta x_{b}}=\mathrm{P}\left(y=1 \mid x_{-b}, x_{b}=1\right)-\mathrm{P}\left(y=1 \mid x_{-b}, x_{b}=0\right) \text { (discrete change of } x_{b}\right)
\end{gathered}
$$

The $\mathrm{mfx}$ with dydx (partial derivatives) computes marginal effects for continuous covariates and discrete changes for binary variables at the reference points after the estimation of a linear or nonlinear regression model. Stata by default uses means of independent variables as reference points.

Table 2 represents the descriptive statistics of variables used in the study and reports the results of the Mann-Whitney U test. The Mann-Whitney Test (MWT) is characterized as a non-parametric test that is applied for comparison between two independent groups. The average earning per share (EPS) is 17.85 with 29.11 standard deviations. It shows that sample firms are highly profitable. Moreover, user firms have a significantly higher earnings ratio than non-user firms. The average size is 25.76 million, which shows an adequate level of firms' size regarding total assets. It implies that larger sized firms are more likely to use derivatives for hedging purposes due to economies of scale and initial unfamiliar costs associated with derivatives' uses. That may have occurred because of Pakistan derivatives' market situation. In this regard, other studies (Bashir et al. 2013; Chaudhry et al. 2014a; Nova et al. 2015) have reported highly similar results. 
Table 1. Summary of Variables.

\begin{tabular}{ll}
\hline \multicolumn{1}{c}{ Variable } & \\
\hline Dependent & A dummy variable is indicating one if firms use derivatives to mitigate risk, otherwise zero. \\
\hline Use of Derivative (DEV) & \\
\hline Ownership Concentration & No of shares held by top five shareholders divided by total no of shares issued \\
\hline Ratio of Top-5 (RTOP5) & No of shares held by largest shareholder divided by total no of shares issued \\
\hline Ratio of Largest Shareholder (RLS) & No of shares owned by family members divided by total no of shares issued \\
\hline Ratio of Family Ownership (RFO) & No of shares held by associated companies divided by total no of shares \\
\hline Ratio of Associated Company (RAC) & No of shares owned by executives divided by total no of shares issued \\
\hline Ratio of Executive Ownership (REO) & No of shares held by largest director divided by total no of shares issued \\
\hline Ratio of Largest Director (RLD) & \\
\hline Control Variable & Net profit divided by total number of shares outstanding \\
\hline Earnings per Share (EPS) & Log of total assets indicates firms' size. \\
\hline Size & Total debt divided by total assets depicting leverage of the firms. \\
\hline Leverage (LEV) & The ratio of tangible assets divided by total assets indicating financial distress \\
\hline Financial Distress Cost (FDC) & Log of foreign sales depicting foreign exchange risks. \\
\hline Foreign Sale (FS-log) &
\end{tabular}

Table 2. Descriptive Statistics and Man-Whitney U Test.

\begin{tabular}{ccccc}
\hline & Overall Sample & Non-User & Users & Mann-Whitney \\
\hline EPS & 17.85 & 15.87 & 21.26 & $-2.431^{* *}$ \\
SIZE (MM) & $(29.11)$ & $(26.16)$ & $(34.11)$ & \\
& 25.76 & 24.96 & 27.41 & $-4.856^{* * *}$ \\
LVG & $(54.21)$ & $(60.87)$ & $(36.84)$ & \\
& 50.72 & 2.090 & 11.25 & -0.266 \\
FS (MM) & $(49.13)$ & $(23.96)$ & $(78.65)$ & \\
& 3.84 & 2.02 & 3.84 & $-5.241^{* * *}$ \\
FDC & $(7.704)$ & $(5.684)$ & $(7.704)$ & \\
& 0.363 & 0.359 & 0.373 & -1.084 \\
RTOP-5 & 0.363 & 0.359 & 0.373 & \\
& 0.695 & 0.717 & 0.651 & $4.388^{* * *}$ \\
RLS & $(0.169)$ & $(0.158)$ & $(0.182)$ & \\
& 0.393 & 0.408 & 0.362 & $2.911^{* * *}$ \\
RFO & $(0.246)$ & $(0.251)$ & $(0.232)$ & \\
& 0.166 & 0.175 & 0.149 & -0.324 \\
RAC & $(0.228)$ & $(0.237)$ & $(0.205)$ & \\
& 0.387 & 0.411 & 0.340 & $1.948^{* *}$ \\
REO & $(0.386)$ & $(0.421)$ & $(0.298)$ & \\
& 0.00329 & 0.00201 & 0.00593 & $-3.357^{* * *}$ \\
RLD & $(0.0147)$ & $(0.00989)$ & $(0.0213)$ & \\
& 0.0895 & 0.0895 & 0.0737 & -0.396 \\
& $(0.131)$ & $(0.134)$ & $(0.124)$ & \\
\hline \multirow{2***}{*}{$p<0.01, * * p<0.05, * 0<0.1}$. & \\
& & & &
\end{tabular}

The mean leverage ratio is $50.72 \%$. The leverage of derivative users is insignificantly greater than non-derivative users, which demonstrates that derivative using firms are characterized as high debited firms. These insignificant results support the findings documented in Afza and Alam (2011a) who indicated the impact of leverage on firm value in the presence of firms' hedging, which is in contrast with some existing studies (Bashir et al. 2013; Chaudhry et al. 2014b). The mean values of foreign sale and financial distress cost are 3.84 million and $36.3 \%$, respectively. Derivative users have a significantly high log of foreign sales compared to non-derivative users. It signifies that firms that have higher foreign sales tend to rely more on derivative instruments to reduce cash flow volatility. This finding is highly similar to one existing study (Ayturk et al. 2016). Contrastingly, the financial distress cost of 
derivative using firms is insignificantly greater than non-derivative using firms. It is consistent with the argument that higher financial distress costs encourage the firm to make greater use of derivatives to mitigate firms' risk exposures (Nguyen and Faff 2002).

Ownership concentration is measured with different proxies. The ratio of top five shareholders and largest shareholders are 67.5 and 39.3, which, overall, indicates that they hold more than 50\% of ownership. It indicates that the top five and largest shareholders of a firm are less likely to rely on derivatives for hedging purposes due to their interests (Hagelin et al. 2006; Hagelin et al. 2007; Allayannis et al. 2011)

The average ratio of family ownership is $16.6 \%$. Family ownership of derivative users is lower than non-derivative users due to an undiversified portfolio of family-owned firms, whereas, 38.7\% averages the ratio of associated companies. The Mann-Whitney statistics indicate that the ratio of associated companies' ownership is significantly lower for derivative users than non-derivative users. However, the average ratio of executives and largest director are $0.3 \%$ and $8.97 \%$, respectively. The directors, as well as largest directors in the total sample, are $13.8 \%$ and $8.4 \%$ on average, respectively. The findings indicate that high executive ownership is found to be more involved in managing risk by using derivatives, whereas, the ratio of the largest director shows an insignificant relationship. In this regard, some existing studies have provided similar results (Hagelin et al. 2006; Kim et al. 2013; Tungsong and Jiraporn 2017).

Table 3 presents the correlation analysis of the independent variables of this study. The correlation coefficient indicates that size has a positive and significant relationship with EPS. Firms holding more assets are highly profitable. Total assets have a positive correlation with sales of the firm, size of the firm, return on assets (ROA), return on equity (ROE), top five shareholders, and the largest shareholder, whereas, total assets exhibit a negative relationship with leverage, log of foreign sales, financial distress costs, family ownership, executives' ownership, and associated companies' ownership. The coefficients of size portray that large-sized firms using derivatives have high leverage, more foreign sales, lower financial distress cost, more ROA and ROE, lower family ownership, more executives, and largest shareholders' ownership. However, leverage of the firm reveals a significant negative association with foreign sales, largest shareholder's ownership, and associated companies' ownership. It also indicates a significant positive relationship between leverage and family shareholding, and executive ownership and largest director ownership. The coefficients also suggest that high financial distress costs lead toward more family ownership and largest director ownership. The largest shareholders of the firms employing derivative instruments are negatively correlated with family ownership and executive ownership but positively correlated with associated companies' ownership. Contrastingly, the coefficients of family ownership signify a positive association with executive ownership, while representing a negative relationship with associated companies' ownership. Similarly, the coefficient of executive ownership depicts lower associated companies' holdings in the presence of executive owners.

Table 4 presents the results of logistic regression with marginal change. A total of six models are generated by employing different measurements of ownership concentration. The total firm-year observations are 700. All regressions are reported with different model selection criteria, such as the Bayesian information criterion (BIC) and the Akaike information criterion (AIC). A coefficient is the corresponding logarithmic transformed odds ratio. For example, the coefficient of RTOP-5 is $-2.440=$ $\mathrm{LN}(0.087161)=\exp (-2.440)$. 
Table 3. Correlation Matrix.

\begin{tabular}{|c|c|c|c|c|c|c|c|c|c|c|c|}
\hline Variable & EPS & SIZE & LVG & FS-log & FDC & RTOP-5 & RLS & RFO & RAC & REO & RLD \\
\hline EPS & 1 & $0.2240^{* * *}$ & -0.0544 & 0.0688 * & $-0.1976^{* * *}$ & $0.1291 * * *$ & $0.1178^{* * *}$ & $-0.1289^{* * *}$ & $0.1442^{* * *}$ & -0.0031 & $-0.1441^{* * *}$ \\
\hline SIZE & & 1 & $-0.1565^{* * *}$ & $0.1482 * * *$ & $-0.0661 *$ & 0.0689 & $0.1695^{* * *}$ & $-0.2269^{* * *}$ & $0.1008^{* * *}$ & 0.0329 & $-0.2186^{* * *}$ \\
\hline LVG & & & 1 & -0.0635 * & 0.0424 & -0.0054 & -0.0739 ** & $0.0762 * *$ & $-0.0917^{* *}$ & 0.0666 * & $0.0852^{* *}$ \\
\hline FS-log & & & & 1 & 0.0553 & $-0.1095^{* * *}$ & -0.0512 & $0.1982^{* * *}$ & -0.0417 & $0.1041^{* * *}$ & $0.1394^{* * *}$ \\
\hline FDC & & & & & 1 & $-0.0970^{* * *}$ & $-0.1449^{* * *}$ & $0.2215^{* * *}$ & $-0.1366^{* * *}$ & -0.0103 & $0.2292 * * *$ \\
\hline RTOP-5 & & & & & & 1 & $0.6869^{* * *}$ & $-0.2287^{* * *}$ & $0.4293^{* * *}$ & -0.2031 & $-0.0806^{* * *}$ \\
\hline RLS & & & & & & & 1 & $-0.3459 * * *$ & $0.3792 * * *$ & $-0.1621^{* * *}$ & $-0.1786^{* * *}$ \\
\hline RFO & & & & & & & & 1 & $-0.5280^{* * *}$ & $0.1177^{* * *}$ & $0.8645^{* * *}$ \\
\hline RAC & & & & & & & & & 1 & $-0.1199^{* * *}$ & $-0.4613^{* * *}$ \\
\hline REO & & & & & & & & & & 1 & 0.0403 \\
\hline RLD & & & & & & & & & & & 1 \\
\hline
\end{tabular}


Table 4. Logistic Regression Analysis.

\begin{tabular}{|c|c|c|c|c|c|c|c|c|c|c|c|c|}
\hline \multirow{2}{*}{ Variable } & \multicolumn{2}{|c|}{ Model 1} & \multicolumn{2}{|c|}{ Model 2} & \multicolumn{2}{|c|}{ Model 3} & \multicolumn{2}{|c|}{ Model 4} & \multicolumn{2}{|c|}{ Model 5} & \multicolumn{2}{|c|}{ Model 6} \\
\hline & Raw & Mfx & Raw & Mfx & Raw & Mfx & Raw & Mfx & Raw & Mfx & Raw & Mfx \\
\hline RTOP-5 & & & $\begin{array}{c}-2.440^{* * *} \\
(-4.78)\end{array}$ & $\begin{array}{c}-0.522 \text { *** } \\
(0.109)\end{array}$ & & & & & & & & \\
\hline RLS & & & & & $\begin{array}{c}-1.111^{* * *} \\
(-2.77)\end{array}$ & $\begin{array}{c}-0.239 * * * \\
(0.0857)\end{array}$ & & & & & & \\
\hline RFO & & & & & & & $\begin{array}{c}-0.783^{* * *} \\
(-1.90)\end{array}$ & $\begin{array}{l}-0.168 * \\
(0.0884)\end{array}$ & & & & \\
\hline RAC & & & & & & & & & $\begin{array}{c}-0.736 \text { *** } \\
(-2.58)\end{array}$ & $\begin{array}{c}-0.158^{* * *} \\
(0.0608)\end{array}$ & & \\
\hline REO & & & & & & & & & & & $\begin{array}{c}14.38^{*} \\
(2.48)\end{array}$ & $\begin{array}{c}3.093^{* * *} \\
(1.251)\end{array}$ \\
\hline RLD & & & & & & & & & & & $\begin{array}{c}-1.343^{* * *} \\
(-1.82)\end{array}$ & $\begin{array}{c}-0.289 * \\
(0.158)\end{array}$ \\
\hline EPS & $\begin{array}{c}0.00524 \\
(1.81)\end{array}$ & $\begin{array}{c}0.00113^{*} \\
(0.000624)\end{array}$ & $\begin{array}{c}0.00702 * * \\
(2.38)\end{array}$ & $\begin{array}{c}0.00150 * \\
(0.000632)\end{array}$ & $\begin{array}{c}0.00583^{* *} \\
(2.01)\end{array}$ & $\begin{array}{l}0.00125^{* *} \\
(0.000623)\end{array}$ & $\begin{array}{c}0.00499 \text { * } \\
(1.71)\end{array}$ & $\begin{array}{c}0.00107 \text { * } \\
(0.000628)\end{array}$ & $\begin{array}{c}0.00610 \text { ** } \\
(2.09)\end{array}$ & $\begin{array}{l}0.00131 * * \\
(0.000626)\end{array}$ & $\begin{array}{c}0.00498^{*} \\
(1.71)\end{array}$ & $\begin{array}{c}0.00107^{*} \\
(0.000625)\end{array}$ \\
\hline SIZE & $\begin{array}{c}0.215^{* * *} \\
(3.68)\end{array}$ & $\begin{array}{c}0.0464^{* * *} \\
(0.0125)\end{array}$ & $\begin{array}{c}0.230 * * * \\
(3.88)\end{array}$ & $\begin{array}{c}0.0493^{* * *} \\
(0.0126)\end{array}$ & $\begin{array}{c}0.243^{* * *} \\
(4.07)\end{array}$ & $\begin{array}{c}0.0522 * * * \\
(0.0127)\end{array}$ & $\begin{array}{c}0.191^{* * *} \\
(3.19)\end{array}$ & $\begin{array}{c}0.0411^{* * *} \\
(0.0128)\end{array}$ & $\begin{array}{c}0.226^{* * *} \\
(3.87)\end{array}$ & $\begin{array}{c}0.0484^{* * *} \\
(0.0124)\end{array}$ & $\begin{array}{c}0.190 * * * \\
(3.17)\end{array}$ & $\begin{array}{c}0.0409^{* * *} \\
(0.0128)\end{array}$ \\
\hline LVG & $\begin{array}{c}0.00586^{* * *} \\
(2.59)\end{array}$ & $\begin{array}{l}0.00126^{* * *} \\
(0.000489)\end{array}$ & $\begin{array}{c}0.00573^{* * *} \\
(2.64)\end{array}$ & $\begin{array}{l}0.00123^{* * *} \\
(0.000466)\end{array}$ & $\begin{array}{c}0.00561 \\
(2.49)\end{array}$ & $\begin{array}{l}0.00120^{* *} \\
(0.000486)\end{array}$ & $\begin{array}{c}0.00593 \text { ** } \\
(2.67)\end{array}$ & $\begin{array}{l}0.00128^{* *} \\
(0.000480)\end{array}$ & $\begin{array}{c}0.00540 \text { ** } \\
(2.41)\end{array}$ & $\begin{array}{l}0.00116^{* *} \\
(0.000482)\end{array}$ & $\begin{array}{c}0.00597^{* * *} \\
(2.56)\end{array}$ & $\begin{array}{c}0.00128^{* * *} \\
(0.000504)\end{array}$ \\
\hline FS-log & $\begin{array}{c}0.0499 * * * \\
(3.98)\end{array}$ & $\begin{array}{c}0.0108^{* * *} \\
(0.00269)\end{array}$ & $\begin{array}{c}0.0424^{* * *} \\
(3.31)\end{array}$ & $\begin{array}{c}0.00907^{* * *} \\
(0.00273)\end{array}$ & $\begin{array}{c}0.0477^{* * *} \\
(3.78)\end{array}$ & $\begin{array}{l}0.0102 * * * \\
(0.00269)\end{array}$ & $\begin{array}{c}0.0562 \\
(4.32)\end{array}$ & $\begin{array}{l}0.0121^{* * *} \\
(0.00278)\end{array}$ & $\begin{array}{c}0.0490 * * * \\
(3.88)\end{array}$ & $\begin{array}{c}0.0105^{* * *} \\
(0.00269)\end{array}$ & $\begin{array}{c}0.0510^{* * *} \\
(3.95)\end{array}$ & $\begin{array}{c}0.0110^{* * *} \\
(0.00275)\end{array}$ \\
\hline FDC & $\begin{array}{l}0.706 \\
(1.32)\end{array}$ & $\begin{array}{c}0.152 \\
(0.116)\end{array}$ & $\begin{array}{l}0.621 \\
(1.13)\end{array}$ & $\begin{array}{c}0.133 \\
(0.117)\end{array}$ & $\begin{array}{l}0.558 \\
(1.03)\end{array}$ & $\begin{array}{c}0.120 \\
(0.117)\end{array}$ & $\begin{array}{c}0.924^{*} \\
(1.68)\end{array}$ & $\begin{array}{l}0.199 * \\
(0.118)\end{array}$ & $\begin{array}{l}0.510 \\
(0.94)\end{array}$ & $\begin{array}{c}0.109 \\
(0.117)\end{array}$ & $\begin{array}{c}0.942 * \\
(1.71)\end{array}$ & $\begin{array}{l}0.203 * \\
(0.118)\end{array}$ \\
\hline Pseudo R2 & \multicolumn{2}{|c|}{0.0549} & \multicolumn{2}{|c|}{0.0815} & \multicolumn{2}{|c|}{0.0641} & \multicolumn{2}{|c|}{0.0591} & \multicolumn{2}{|c|}{0.0631} & \multicolumn{2}{|c|}{0.0661} \\
\hline LR Chi2 & \multicolumn{2}{|c|}{48.48} & \multicolumn{2}{|c|}{72.01} & \multicolumn{2}{|c|}{56.66} & \multicolumn{2}{|c|}{52.21} & \multicolumn{2}{|c|}{55.71} & \multicolumn{2}{|c|}{58.44} \\
\hline Prob. & \multicolumn{2}{|c|}{0.0000} & \multicolumn{2}{|c|}{0.0000} & \multicolumn{2}{|c|}{0.0000} & \multicolumn{2}{|c|}{0.0000} & \multicolumn{2}{|c|}{0.0000} & \multicolumn{2}{|c|}{0.0000} \\
\hline AIC & \multicolumn{2}{|c|}{847.1} & \multicolumn{2}{|c|}{825.5} & \multicolumn{2}{|c|}{840.9} & \multicolumn{2}{|c|}{845.3} & \multicolumn{2}{|c|}{841.8} & \multicolumn{2}{|c|}{841.1} \\
\hline $\mathrm{BIC}$ & \multirow{2}{*}{\multicolumn{2}{|c|}{$\begin{array}{c}874.4 \\
700\end{array}$}} & \multicolumn{2}{|c|}{857.4} & 87 & & & & & & & \\
\hline$N$ & & & & & 7 & & & & & & & \\
\hline
\end{tabular}


Model 1 shows the results without including ownership variables. The EPS shows a positive and significant $(\beta=0.00524, p<0.1)$ relationship with derivative usage. It postulates that high profitability tends to increase the need for hedging for firms due to tax incentives or to reduce the expected tax liability. From this point of view, some previous studies have achieved similar results, such as (Carter et al. 2003, 2006), but Allayannis and Weston (2001) results are in contrast. The results show that size has a positive and significant $(\beta=2.15, p \leq 0.01)$ impact on the use of derivative instruments. It shows that firms that are larger are more likely to rely on derivatives' usage than small ones. The reason may be that they want to exploit the advantage of economies of scale to reduce fixed costs. Some previous studies have obtained similar results in this regard (Fok et al. 1997; Bashir et al. 2013; Nova et al. 2015; Ayturk et al. 2016). Leverage also has a positive and statistically significantly $(\beta=0.00586, p<0.01)$ relationship with derivatives' usage. It implies that highly leveraged firms tend to make more use of derivatives to fully hedge cash flows due to the convexity of capital costs. The findings of Tashfeen et al. (2017) are the same in this regard. The log of foreign sales has a positive and significant $(\beta=0.0499, p<0.01)$ impact on derivative usage as firms involved in the export of goods or services make greater use of derivatives for hedging purposes due to mitigation of foreign exchange risk. Ayturk et al. (2016) reported consistent findings regarding this and concluded that the use of derivatives helps to enhance firms' value. Moreover, financial distress cost has a positive, but statistically insignificant $(\beta=0.706)$, relationship with the use of derivatives. It indicates that those firms that make more use of derivatives have high financial distress costs to reduce firms' risk exposures (El-Masry 2006; Nova et al. 2015). The model has a 5.49\% Pseudo $R^{2}$, and, overall, the model is a good fit. The model also shows the marginal change of all independent variables.

Model 2 employs the ratio of top five shareholders with other independent variables. The results prove that it has a negative and significant $(\beta=-2.440, p<0.01)$ relationship with derivative usage. It delineates that high ownership concentration leads to the lower use of derivatives to truncate risk due to the private interest of controlling shareholders. The marginal change coefficient shows that if the ratio of top five shareholders changes by $1 \%$, the derivatives' users decrease by -0.522 , which is significant at $1 \%$. The Pseudo $\mathrm{R}^{2}$ of the model is $8.15 \%$.

Model 3 depicts the regression analysis regarding ownership concentration of the largest shareholder in the firm. The finding represents that the ratio of the most significant shareholder has a negative and statistically significant $(\beta=-1.111, p<0.01)$ impact on derivatives' usage. It reveals that highly concentrated ownership leads to less use of derivatives to curtail interest rate and foreign exchange exposures due to their benefits in the firm. The findings also imply that more control in fewer hands tends to reduce the firms' value, especially in the eyes of external investors (Pinkowitz et al. 2007). Moreover, $1 \%$ change as the ratio of largest shareholders brings -0.239 change in the users of derivatives. The results regarding control variables are the same as in Model 1. The model, overall, explains $6.41 \%$ of the variation in the dependent variable.

Model 4 includes family ownership as the ownership concentration. The findings indicate that the ratio of family ownership has a negative and significant $(\beta=-0.783, p<0.01)$ relation with derivatives' usage. It also portrays that family owners with the highest control are less likely to make use of derivatives for hedging purpose because of having an undiversified ownership position. This finding supports the evidence documented by Hagelin et al. (2006) who revealed that family firms do not rely on risk management techniques due to poor portfolio diversification, while being inconsistent with Tungsong and Jiraporn (2017), who viewed that family ownership does not have a significant effect on firms' hedging. The value of the marginal coefficient shows a significant negative change in user by changing $1 \%$ in family ownership. The model has a $5.91 \%$ Pseudo $R^{2}$.

Model 5 uses the ratio of the associated company as a proxy for ownership concentration. The findings indicate a negative and highly significant relationship between the ratio of associated companies and the use of derivatives. Associated companies that have ownership concentration within the firms are less involved in the use of derivatives to reduce volatility in their cash flows. Also, the Mfx model proves that there is a significant inverse change in the users of derivatives if 
associated firms increase their ownership by $1 \%$. What the variation explains by the model is $6.31 \%$ in the dependent variable.

Moreover, results related to the control variables support the findings of the regression analysis, as in Model 1 and Model 2. Lastly, in Model 6, the ratio of executive ownership has a positive and significant $(\beta=14.38, p<0.1)$ impact on derivative usage. It may be signaling that concentrated executive owners are more likely to engage in hedging activities because of increasing the value of their stocks, which, ultimately, lead toward better firms' performance. Whereas, the ratio of largest director has a significant negative relationship with derivative usage. The marginal coefficients also have some significant change in the user of derivatives. These results support the findings of (Bettis et al. 2015; Whalley 2008). Model 6 explains 6.61\% variation in the dependent variable.

\section{Discussion and Conclusions}

The present study has investigated the impact of ownership concentration on firms' hedging from a new perspective. Prior scholars have studied the determinants of derivatives, but none of the studies considered the effect of ownership concentration on derivative use. This study first sheds light on the comparison of derivative users and non-derivative users by applying the Mann-Whitney test. Then, logistic regression was used to analyze the impact of ownership concentration and firms' hedging. The empirical results indicate that ownership concentration has a significant negative impact on the use of derivatives except for executive ownership. Large sized firms are more likely to rely on hedging activities due to economies of scale and initial unfamiliar costs related to derivatives' usage that might have happened because of Pakistan's derivative market situation. Leverage was significantly related to firms' hedging due to firms' ability to pay financial costs and to fully hedge cash flows because of the convexity of capital costs, which, ultimately, led to firms' higher values. Hence, firms that have high foreign sales also make greater use of derivatives for hedging purposes due to the mitigation of foreign exchange risks. In contrast, high financial distress costs encourage firms to involve themselves in hedging activities to reduce firms' risk exposures. Likewise, high profitability (EPS) tends to increase the need for hedging for firms due to tax incentives or to reduce the expected tax liability.

However, the results also delineate that ownership concentration tends to reduce the uses of derivatives hedging activities due to concentrated owners' interests. Top five shareholders and largest shareholder had a negative association with hedging due to their private benefits in the firm. Likewise, family owners with the highest control are less likely to involve in hedging because they have an undiversified ownership position, which also explains why they are involved in extracting personal benefits at the cost of minority shareholders. Moreover, in Pakistan, families are less educated, and they have a lack of knowledge regarding the usage of derivative instruments for hedging purposes. This study also depicts that associated companies were less involved in hedging activities. Executive owners were more likely to engage in hedging activities to increase the value of their stock, which, ultimately, leads toward firms' better performance. Firms that were highly concentrated by the most significant director were found to be reluctant to use derivatives.

This empirical investigation is a valuable addition to the research of derivatives. Past work has primarily focused on managerial ownership and family ownership, separately. None of the research has focused on ownership concentration as a determinant of derivative usage. The former research work was centred on the developed nation. The present research is, therefore, an excellent contribution to the available literature. This study provides policy guidelines for Pakistani corporations that aim to make optimal use of derivative instruments for reducing interest rates, foreign exchange rates, commodity prices, and equity price exposures. It also recommends that policymakers must develop a well-established derivative market in Pakistan to create awareness of derivatives' usage and to facilitate firms that have high foreign sales and more volatility in their cash flows.

Future researchers should focus on the relationship between ownership concentration and hedging in the case of financial firms. This research effort was undertaken by using dummy variables of 
derivative usage. Due to some implicit barriers, we could not consider the notional value of derivatives. However, we have provided a way so that future researchers can have a more in-depth analysis of this relationship by overcoming this shortcoming.

Author Contributions: All authors contributed equally to this work. All authors wrote, reviewed and commented on the manuscript. All authors have read and approved the final manuscript. Conceptualization, A.A.B.; Methodology, A.S.; Formal Analysis, M.S.N.; Data Curation, H.A. \& A.A.B.; Writing-Original Draft Preparation, A.A.B.; Writing-Review \& Editing, A.S.

Funding: This research received no external funding

Conflicts of Interest: The authors declare no conflicts of interest.

\section{References}

Adkins, Lee C., David A. Carter, and W. Gary Simpson. 2007. Managerial Incentives and the Use of Foreign-Exchange Derivatives by Banks. Journal of Financial Research 30: 399-413. [CrossRef]

Afza, Talat, and Atia Alam. 2011a. Determinants of Extent of Financial Derivative Usage. African Journal of Business Management 5: 8331.

Afza, Talat, and Atia Alam. 2011b. Corporate Derivatives and Foreign Exchange Risk Management: A Case Study of Non-financial Firms of Pakistan. The Journal of Risk Finance 12: 409-20. [CrossRef]

Allayannis, George, Ugur Lel, and Darius P. Miller. 2011. The Use of Foreign Currency Derivatives, Corporate Governance, and Firm Value around the World. Journal of International Economics 87: 65-87. [CrossRef]

Allayannis, George, and Eli Ofek. 2001. Exchange Rate Exposure, Hedging, and the Use of Foreign Currency Derivatives. Journal of International Money and Finance 20: 273-96. [CrossRef]

Allayannis, George, and James P. Weston. 2001. The Use of Foreign Currency Derivatives and Firm Market Value. The Review of Financial Studies 14: 243-76. [CrossRef]

Al-Shboul, Mohammad, and Stewart Alison. 2009. The Effects of the Use of Corporate Derivatives on the Foreign Exchange Rate Exposure. Journal of Accounting, Business \& Management 16: 72-92.

Anton, Sorin Gabriel. 2013. Who Manages Financial Risk? An Empirical Examination of Risk Management Practices in the Romanian Metallurgical Industry. Metalurgija 52: 518-20.

Ayturk, Yusuf, Ali Osman Gurbuz, and Serhat Yanik. 2016. Corporate Derivatives Use and Firm Value: Evidence from Turkey. Borsa Istanbul Review 16: 108-20. [CrossRef]

Bartram, Söhnke M., Gregory W. Brown, and Jennifer Conrad. 2011. The Effects of Derivatives on Firm Risk and Value. The Journal of Financial and Quantitative Analysis 46: 967-99. [CrossRef]

Bashir, Hamid, Khurram Sultan, and Omar Khazaal Jghef. 2013. Impact of Derivatives Usage on Firm Value: Evidence from Non Financial Firms of Pakistan. Journal of Management Research 5: 108-27. [CrossRef]

Berkman, Henk, Michael E. Bradbury, and Stephen Magan. 1997. An International Comparison of Derivatives Use. Financial Management 26: 69-73. [CrossRef]

Bessembinder, Hendrik. 1991. Forward Contracts and Firm Value: Investment Incentive and Contracting Effects. Journal of Financial and Quantitative Analysis 26: 519-32. [CrossRef]

Bettis, Carr, John Bizjak, and Swaminathan Kalpathy. 2015. Why Do Insiders Hedge Their Ownership? An Empirical Examination. Financial Management 44: 655-83. [CrossRef]

Bodnar, Gordon M., Gregory S. Hayt, and Richard C. Marston. 1998. 1998 Wharton Survey of Financial Risk Management by US Non-Financial Firms. Financial Management 27: 70-91. [CrossRef]

Borokhovich, Kenneth A., Kelly R. Brunarski, Claire E. Crutchley, and Betty J. Simkins. 2004. Board Composition and Corporate Use of Interest Rate Derivatives. Journal of Financial Research 27: 199-216. [CrossRef]

Boubaker, Sabri, Salma Mefteh, and Junaid M. Shaikh. 2010. Does Ownership Structure Matter in Explaining Derivatives' Use Policy in French Listed Firms. International Journal of Managerial and Financial Accounting 2: 196-212. [CrossRef]

Carter, David A., Daniel A. Rogers, and Betty J. Simkins. 2003. Does Fuel Hedging Make Economic Sense? The Case of the US Airline Industry. Available online: https:/ / papers.ssrn.com/sol3/papers.cfm?abstract_id=325402 (accessed on 22 January 2018).

Carter, David A., Daniel A. Rogers, and Betty J. Simkins. 2006. Does Hedging Affect Firm Value? Evidence from the US Airline Industry. Financial Management 35: 53-86. [CrossRef] 
Chaudhry, Naveed Iqbal, Mian Saqib Mehmood, and Asif Mehmood. 2014a. Dynamics of Derivatives Usage and Firm's Value. SSRN Scholarly Paper ID 2460842. Rochester: Social Science Research Network. Available online: https:/ / papers.ssrn.com/abstract=2460842 (accessed on 23 January 2018).

Chaudhry, Naveed Iqbal, Mian Saqib Mehmood, and Asif Mehmood. 2014b. Determinants of Corporate Hedging Policies and Derivatives Usage in Risk Management Practices of Non-Financial Firms, July. Available online: https: / / papers.ssrn.com/abstract=2470956 (accessed on 23 January 2018).

Dionne, Georges, and Thouraya Triki. 2013. On Risk Management Determinants: What Really Matters? The European Journal of Finance 19: 145-64. [CrossRef]

El-Masry, Ahmed A. 2006. Derivatives Use and Risk Management Practices by UK Nonfinancial Companies. Managerial Finance 32: 137-59. [CrossRef]

Fok, Robert C. W., Carolyn Carroll, and Ming C. Chiou. 1997. Determinants of Corporate Hedging and Derivatives: A Revisit. Journal of Economics and Business 49: 569-85. [CrossRef]

Géczy, Christopher C., Bernadette A. Minton, and Catherine M. Schrand. 2007. Taking a View: Corporate Speculation, Governance, and Compensation. The Journal of Finance 62: 2405-43. [CrossRef]

Geczy, Christopher, Bernadette A. Minton, and Catherine Schrand. 1997. Why Firms Use Currency Derivatives. The Journal of Finance 52: 1323-54. [CrossRef]

Graham, John R., and Daniel A. Rogers. 2002. Do Firms Hedge in Response to Tax Incentives? The Journal of Finance 57: 815-39. [CrossRef]

Grant, Kevin, and Andrew P. Marshall. 1997. Large UK Companies and Derivatives. European Financial Management 3: 191-208. [CrossRef]

Guay, Wayne R. 1999. The Impact of Derivatives on Firm Risk: An Empirical Examination of New Derivative Users. Journal of Accounting and Economics 26: 319-51. [CrossRef]

Hagelin, Niclas. 2003. Why Firms Hedge with Currency Derivatives: An Examination of Transaction and Translation Exposure. Applied Financial Economics 13: 55-69. [CrossRef]

Hagelin, Niclas, Martin Holmen, John D. Knopf, and Bengt Pramborg. 2007. Managerial Stock Options and the Hedging Premium. European Financial Management 13: 721-41. [CrossRef]

Hagelin, Niclas, Martin Holmén, and Bengt Pramborg. 2006. Family Ownership, Dual-Class Shares, and Risk Management. Global Finance Journal 16: 283-301. [CrossRef]

Haushalter, G. David. 2000. Financing Policy, Basis Risk, and Corporate Hedging: Evidence from Oil and Gas Producers. The Journal of Finance 55: 107-52. [CrossRef]

Horng, Yuh-Sheng, and Peihwang Wei. 1999. An Empirical Study of Derivatives Use in the REIT Industry. Real Estate Economics 27: 561-86. [CrossRef]

Huang, Sterling, Urs Peyer, and Benjamin Segal. 2013. Do Firms Hedge Optimally? Evidence from an Exogenous Governance Change. Available online: https://papers.ssrn.com/sol3/papers.cfm?abstract_id=2312263 (accessed on 24 January 2018).

Kim, Chansog, Christos Pantzalis, and Jung Park. 2013. Do Family Owners Use Firm Hedging Policy to Hedge Personal Undiversified Wealth Risk? Financial Management 43. [CrossRef]

Lel, Ugur. 2012. Currency Hedging and Corporate Governance: A Cross-Country Analysis. Journal of Corporate Finance 18: 221-37. [CrossRef]

Leland, Hayne E. 1998. Agency Costs, Risk Management, and Capital Structure. The Journal of Finance 53: $1213-43$. [CrossRef]

Levi, Maurice D. 1996. International Finance: The Markets and Financial Management of Multinational Business. New York: McGraw-Hill.

Mahmood, Mazhar, and Kashif-ur- Rehman. 2010. Derivative Usage in Corporate Pakistan: A Qualitative Research of Listed Companies. The International Business \& Economics Research Journal 9: 151-58. [CrossRef]

Nguyen, Hoa, and Robert Faff. 2002. On The Determinants of Derivative Usage by Australian Companies. Australian Journal of Management 27: 1-24. [CrossRef]

Nova, Mariana, António Cerqueira, and Elísio Brandão. 2015. Hedging With Derivatives and Firm Value: Evidence for the Non Fnancial Frms Listed on the London Stock Exchange. FEP Working Papers 568. Porto: Universidade do Porto, Faculdade de Economia do Porto.

Osuoha, John Ifeanyichukwu. 2013. Transforming Nigeria Economy through the Use of Derivatives. Advances in Applied Economics and Finance 4: 668-77. 
Osuoha, John Ifeanyichukwu, Samy Martin, and Ebun-Oluwa Oluwatoyin Osuoha. 2015. The Impact of Corporate Governance on Derivatives Usage-Empirical Evidence from African Non-Financial Firms. British Journal of Economics, Management \& Trade 8: 19-31.

Pinkowitz, Lee, Rohan Williamson, and René M. Stulz. 2007. Cash Holdings, Dividend Policy, and Corporate Governance: A Cross-Country Analysis. Journal of Applied Corporate Finance 19: 81-87. [CrossRef]

Smith, Clifford W., and Rene M. Stulz. 1985. The Determinants of Firms' Hedging Policies. The Journal of Financial and Quantitative Analysis 20: 391-405. [CrossRef]

Spanò, Marcello. 2007. Managerial Ownership and Corporate Hedging. Journal of Business Finance E Accounting 34: $1245-80$.

Tashfeen, Rubeena, and Tashfeen Azhar. 2016. Understanding the Relationship between Corporate Governance and Financial Derivatives. SSRN Scholarly Paper ID 2886994. Rochester: Social Science Research Network. Available online: https:/ / papers.ssrn.com/abstract=2886994 (accessed on 25 January 2018).

Tashfeen, Rubeena, Tashfeen Azhar, and Saad Ullah. 2017. Corporate Governance, Financial Derivatives and Firm Size. SSRN Scholarly Paper ID 2933024. Rochester: Social Science Research Network. Available online: https: / / papers.ssrn.com/abstract=2933024 (accessed on 25 January 2018).

Titman, Sheridan. 1992. Interest Rate Swaps and Corporate Financing Choices. The Journal of Finance 47: 1503-16. [CrossRef]

Tufano, Peter. 1996. Who Manages Risk? An Empirical Examination of Risk Management Practices in the Gold Mining Industry. The Journal of Finance 51: 1097-137. [CrossRef]

Tungsong, Sachapon, and Pornsit Jiraporn. 2017. The Effect of Family Ownership on Corporate Hedging: The Case of Thailand. Applied Economics Letters 24: 882-87. [CrossRef]

Wang, Xuequn, and Lida Fan. 2011. The Determinants of Corporate Hedging Policies. International Journal of Business and Social Science 2: 29-38.

Whalley, A. Elizabeth. 2008. Effect of Executive Share Ownership and Private Hedging on Executive Stock Option Exercise and Values. In Warwick Business School. Available online: http:/ / www.warwick.ac.uk/fac/soc/ wbs/subjects / finance/faculty1/elizabeth_whalley/esohedging.pdf (accessed on 26 January 2018).

Zhang, Haiwen. 2009. Effect of Derivative Accounting Rules on Corporate Risk-Management Behavior. Journal of Accounting and Economics 47: 244-64. [CrossRef]

(C) 2018 by the authors. Licensee MDPI, Basel, Switzerland. This article is an open access article distributed under the terms and conditions of the Creative Commons Attribution (CC BY) license (http:/ / creativecommons.org/licenses/by/4.0/). 